\title{
Pembuatan Kompos Sampah Dapur dan Taman dengan Bantuan Aktivator EM4
}

\section{Kitchen and Garden Waste Composting using EM4 Activator}

\author{
Sri Hastuti*, Tri Martini, Pranoto, Candra Purnawan, Abu Masykur, Atmanto Heru Wibowo \\ Program Studi Kimia, Fakultas Matematika dan Pengetahuan Alam, Universitas Sebelas Maret \\ Jl. Ir. Sutami 36A Kentingan, Surakarta, Indonesia, 57126 \\ *E-mail: hastuti.uns@gmail.com
}

\begin{abstract}
Abstrak. Pembuatan kompos dari sampah dapur dan taman dengan bantuan effective microorganism (EM4) dan microorganism local (MOL) telah dilakukan. Tujuan dari kegiatan ini adalah memanfaatkan sampah yang ada di sekitar untuk dijadikan barang yang lebih berguna. EM4 merupakan kultur campuran dari mikroorganisme yang menguntungkan yang mengandung mikroorganisme fermentasi dan sintetik yang terdiri dari bakteri Asam Laktat (Lactobacillus Sp), bakteri Fotosentetik (Rhodopseudomonas Sp), Actinomycetes Sp, Streptomyces Sp dan Yeast (ragi) dan Jamur pengurai selulose. Bahan ini membantu fermentasi bahan organik tanah menjadi senyawa organik yang mudah diserap oleh akar tanaman. Proses pembuatan kompos dilakukan dengan mencampurkan sampah dapur dan taman dengan penambahan EM4. Proses fermentasi dilakukan variasi waktu 10, 14, 21, 26 dan 32 hari. Hasil pengamatan menunjukkan bahwa semakin lama fermentasi kompos yang dihasilkan semakin baik dimana daun telah hancur berubah bentuk seperti tanah.
\end{abstract}

Kata kunci: EM4, kompos, sampah

Abstract. Composting of kitchen and garden waste with the help of effective microorganisms (EM4) and microorganism local (MOL) has been carried out. The purpose of this activity is to use the waste to become more useful items. EM4 is a mixed culture of beneficial microorganisms. This material contains microorganisms consisting of lactic acid bacteria (Lactobacillus Sp), photosynthetic bacteria (Rhodopseudomonas Sp), Actinomycetes Sp, Streptomyces Sp, and yeast, and cellulose-decomposing fungi. This activator helps break down soil organic matter into organic compounds that are easily absorbed by plant roots. The composting was done by mixing kitchen and garden waste with the addition of EM4 and MOL. The fermentation process was carried out in variations of 10, 14, 21, 26, and 32 days. The results showed that the longer the fermentation time the better the compost was produced indicating by the leaves had crumbled into shape like the soil.

Keywords: Compost, EM4, Garbage

\section{Pendahuluan}

Sampah merupakan barang yang dianggap tidak berguna sehingga harus dimusnahkan [1]. Sampah merupakan bagian yang tidak dapat terpisahkan dari kehidupan manusia, karena pada dasarnya semua manusia pasti menghasilkan sampah. Sampah merupakan suatu buangan yang dihasilkan dari setiap aktivitas manusia. Volume peningkatan sampah sebanding dengan meningkatnya tingkat konsumsi manusia. 
Sampah organik adalah sampah yang banyak dihasilkan dari sisa hasil pertanian, rumah tangga, industri dan tumbuh-tumbuhan [2]. Keberadaan sampah merupakan salah satu permasalahan yang perlu mendapat perhatian. Ketersediaan bahan baku sampah organik disekitar kita mendorong untuk mengolah sampah menjadi produk yang lebih bermanfaat. Salah satunya adalah mengolah sampah organik menjadi pupuk kompos. Effective Micoorganisme (EM4) merupakan kultur campuran dari mikroorganisme yang menguntungkan yang mengandung mikroorganisme fermentasi dan sintetik yang terdiri dari bakteri Asam Laktat (Lactobacillus Sp), Bakteri Fotosentetik (Rhodopseudomonas Sp),Actinomycetes Sp, Streptomyces SP dan Yeast (ragi) dan Jamur pengurai selulose. Bahan ini membantu fermentasi bahan organik tanah menjadi senyawa organik yang mudah diserap oleh akar tanaman. Tujuan penambahan EM4 adalah untuk menguraikan rantai panjang penyusun sampah organic menjadi molekul yang sederhana.

Berbagai penelitian tentang pembuatan kompos telah dilakukan. Optimasi pembuatan kompos dari limbah rumah tangga dengan activator EM4 dan MOL [3]. Kondisi maksimal diperoleh pada perbandingan EM4/Mol antara 0,6 -1,2 dengan waktu fermentasi 14 -30 hari. Pemanfaatan limbah sayur dan MOL untuk pembuatan kompos [4]. Hasilnya menunjukkan bahwa kompos telah terbentuk pada waktu 4 minggu. Pembuatan kompos dari daun kering dengan bantuan MOL [5], hasilnya sesuai standart kompos Indonesia dengan SNI-19-7030-2004 [6]. Kompos dari limbah rumah tangga dengan activator EM4 [7], hasilnya juga sesuai standart kompos Indonesia dengan SNI-19-7030-2004.

Pada penelitian ini dilakukan pembuatan kompos dari sampah dapur dan daun kering dengan bantuan EM4 dan MOL. Selanjutnya diamati perubahan warna selama pengomposan dan hasilnya dibandingkan dengan SNI-19-7030-2004.

\section{Metode}

Bahan bahan yang digunakan antara lain: Daun daun dari sampah dapur, daun kering dari taman, Effective Micoorganisme (EM4), Micoorganisme Local (MOL) / kompos), gula. Peralatan yang digunakan tong sebagai komposter, ember dan gayung.

Menambahkan $50 \mathrm{ml}$ EM4 dan 50 g gula ke dalam 5 liter air, selanjutnya di aduk sampai larut. Sampah dapur dan daun kering taman di campur, kemudian ditambahkan larutan EM4 yang sudah disiapkan. Selanjutnya dimasukan dalam tong komposter yang sebelumnya ditambah MOL (kompos yang sudah jadi). Tong di tutup dan diamati hasilnya.

\section{Hasil dan Pembahasan}

Proses pembuatan kompos pada prinsipnya adalah penguraian rantai panjang penyusun sampah organik menjadi molekul yang sederhana seperti yang ditunjukkan pada reaksi berikut:

$$
\text { Bahan organik } \underset{(\mathrm{EM} 4+\mathrm{MOL})}{\longrightarrow} \mathrm{CO}_{2}+\mathrm{H}_{2} \mathrm{O}+\text { Hara }+ \text { Humus }+ \text { Energi }
$$

Humus merupakan hasil peruraian yang bentuk dan warnanya hitam seperti tanah. Unsur-unsur hara yang terdapat pada kompos menurut SNI-19-7030-2004 ditunjukkan pada Tabel 1.

Tabel 1. Komposisi unsur Makro dalam kompos menurut SNI-19-7030-2004.

\begin{tabular}{cccc}
\hline Unsur Makro & Satuan & Minimal & Maksimal \\
\hline Nitrogen & $\%$ & 0,4 & \\
Karbon & $\%$ & 9,80 & 32 \\
Phosfor & $\%$ & 0,1 & $*$ \\
Kalium & $\%$ & 0,2 & 20 \\
Rasio C/N & & 10 &
\end{tabular}

*Nilai lebih besar dari minimum atau lebih kecil dari maksimum 
Unsur nitrogen pada proses pembuatan kompos biasanya akan terjadi kenaikan. Kondisi ini terjadi karena bahan bahan organik dalam daun akan di urai menjadi asam amino yang selanjutnya akan diubah menjadi nitrat. Kandungan unsur nitrogen ini akan menambah kesuburan tanaman. Unsur ini dibutuhkan tanaman untuk pembentukan asam amino, protein, dan enzim. Unsur karbon digunakan mikroorganisme sebagai energi selama proses peruraian, sehingga kandungan karbon semakin lama waktu fermentasi akan semakin menurun. Hal ini disebabkan sebagaian karbon akan diubah menjadi $\mathrm{CO}_{2}$. Fosfor dalam tanaman berfungsi merangsang pertumbuhan tanaman, akar dan biji. Bahan organik yang mengandung senyawa phospholipid akan di urai menjadi fosfat [5]. Kadar kalium berguna untuk membantu pembentukan protein dan karbohidrat serta untuk daya tahan suatu tanaman. Berdasarkan hasil pengamatan fisik kompos dalam kegiatan ini dapat ditunjukkan pada Gambar 1 dan Tabel 2.

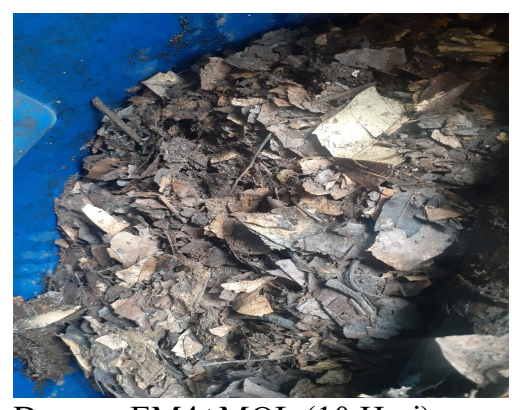

Dengan EM4+MOL (10 Hari)

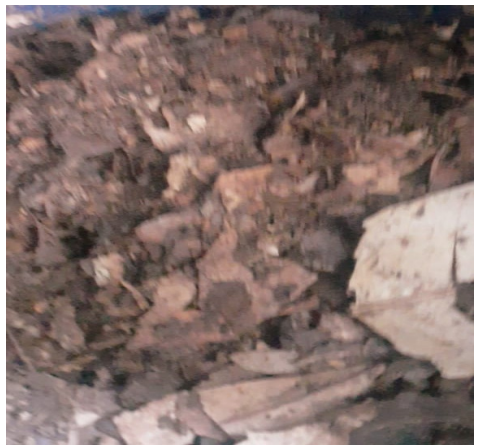

Dengan EM4 +MOL (26 Hari)

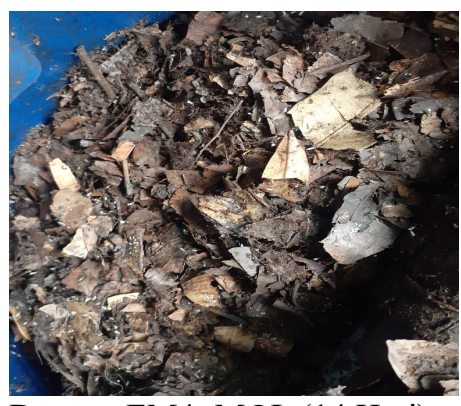

Dengan EM4+MOL (14 Hari)

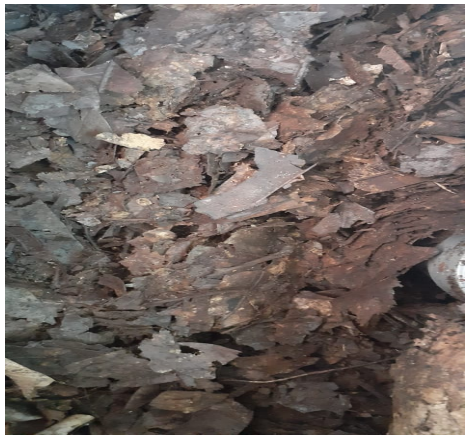

Dengan EM4 +MOL (32 Hari)

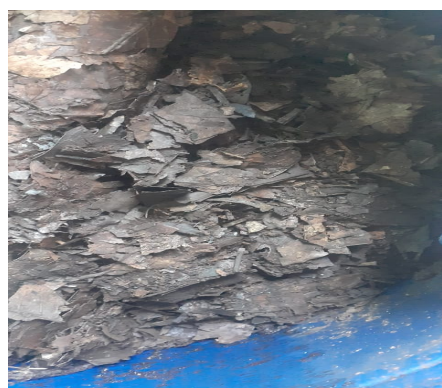

Dengan EM4 +MOL (21 Hari)

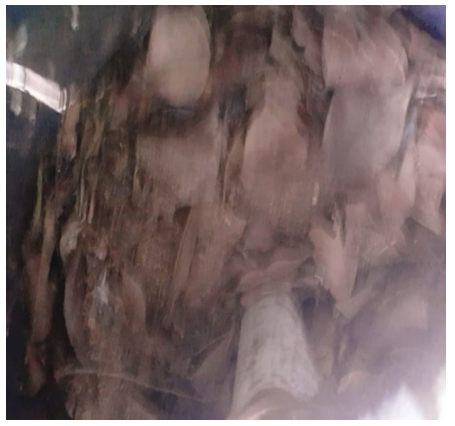

Tanpa EM4+MOL (26 Hari)

Gambar 1. Hasil pengamatan selama proses pembuatan kompos.

Tabel 2. Hasil pengomposan dengan bantuan EM4 dan MOL.

\begin{tabular}{cccc}
\hline Kompos & Bau & Warna & Struktur \\
\hline Hari ke 10 & Seperti tanah & Kecoklatan & Belum terurai sempurna \\
Hari ke 14 & Seperti tanah & Kecoklatan & Belum terurai sempurna \\
Hari ke 21 & Seperti tanah & Kecoklatan & Menggumpal \\
Hari ke 26 & Seperti tanah & Kecoklatan & Menggumpal \\
Hari ke 32 & Seperti tanah & Hitam kecoklatan & Gembur \\
\hline
\end{tabular}

Pada waktu pengomposan selama 10 hari, daun kering dari taman yang semula masih utuh sudah rapuh dan berwarna kehitaman. Hal ini sesuai penelitian Subandriyo dkk, yang menyatakan bahwa proses 
pengomposan terjadi antara 12-30 hari [8]. Semakin lama waktu pengomposan daun daun yang kering semakin rapuh dan akhirnya hancur. Warnanya menjadi hitam seperti tanah. Hal ini sesuai SNI-19-70302004 yang menyatakan bahwa warna kompos adalah hitam seperti tanah. Kondisi ini sangat berbeda sekali dengan daun yang tanpa penambahan EM4 +MOL daun masih utuh belum terurai sama sekali.

\section{Kesimpulan}

Pada fermentasi selama 10 hari daun daun kering sudah rapuh dan berwarna kehitaman. Semakin lama fermentasi kompos yang dihasilkan semakin baik. Semua sampah yang berupa daun telah hancur dan berubah bentuk seperti tanah.

\section{Referensi}

[1] Daryanto, 1995, Masalah Pencemaran, Penerbit Tarsito Bandung, Bandung.

[2] Ekawandani, N., Alvianingsih, 2018, Efektifitas Kompos Daun Menggunakan EM4 dan Kotoran Sapi, TEDC, (12)2.

[3] Subandriyo, Anggoro, D.D, Hadiyanto, 2012, Optimasi Pengomposan Sampah Organik Rumah Tangga Menggunakan Kombinasi Aktivator EM4 dan MOL Terhadap Rasio C/N, J. Ilmu Lingkungan, 10(20): 70-75.

[4] Suwatanti, E, widiyaningrum, P., 2017, Pemanfaatan MOL Limbah Sayur pada Proses Pembuatan Kompos, J. MIPA 40(1): 1-6.

[5] Hadiwidodo, M., Sutrisno, E., Handayani, D.S., Febriani, M.P, 2018, Studi Pembuatan Kompos Padat dari Sampah Daun Kering TPST UNDIP dengan Variasi Bahan Mikroorganisme Lokal (MOL) Daun, J. Presipitasi: Media Komunikasi dan Pengembangan Teknil Lingkungan, 15(2): 7985 .

[6] SNI-19-7030-2004 Sepesifikasi Kompos dari Sampah Organik Domestik.

[7] Rahmawanti, N. dan Dony, N., 2014, Pembuatan Pupuk Organik Berbahan Sampah Organik Rumah Tangga dengan Penambahan Aktivator EM4 di Daerah Kayu Tangi, ZIRAA'AH, 39(1):1-7.

[8] Subandriyo, Anggoro, D.D, Hadiyanto, 2012, Optimasi Pengomposan Sampah Organik Rumah Tangga Menggunakan Kombinasi Aktivator EM4 dan MOL Terhadap Rasio C/N, J. Ilmu Lingkungan, 10(20): 70-75. 